\title{
SLOVAR SODOBNEGA SLOVENSKEGA JEZIKA: LEKSIKOGRAFSKA TRADICIJA IN/ALI INOVACIJA?
}

\section{Polona GANTAR}

Inštitut za slovenski jezik Frana Ramovša ZRC SAZU

Gantar, P. (2014): Slovar sodobnega slovenskega jezika: leksikografska tradicija in/ali inovacija. Slovenščina 2.o, 2 (2): 194-231.

URL: http://www.trojina.org/slovenscina2.o/arhiv/2014/2/Slo2.O_2014_2_10.pdf.

Ko je bil konec maja 2013 objavljen Predlog za izdelavo Slovarja sodobnega slovenskega jezika, se je tako na strokovnih forumih kot v medijih razvila debata o tem, ali naj novi slovar slovenskega jezika sledi leksikografski tradiciji, kot se je oblikovala s Slovarjem slovenskega knjižnega jezika, ali naj se od te tradicije oddalji. Ker so se ob tem oblikovali različni pogledi na razumevanje slovarske tradicije kot tudi na vključevanje sodobnih slovarskih praks, želimo v prispevku na podlagi analize zasnove SSKJ in SNB ter s prispevki, ki se kakorkoli nanašajo na koncept bodočega slovarja slovenskega jezika, ugotoviti, katere elemente leksikografske teorije in prakse lahko pojmujemo kot tradicionalne ter katere so predlagane novosti $\mathrm{v}$ slovenski leksikografiji. Vzporedno predlagamo tudi zasnovo novega slovarja v ključnih segmentih, tj. z vidika uporabnika, medija in uporabe jezikovnotehnološkega znanja, ki bi zadostila opisu sodobnega slovenskega jezika, ki kar v največji meri zadovoljuje potrebe jezikovne skupnosti $\mathrm{v}$ današnjem času in okoliščinah.

Ključne besede: slovar sodobnega slovenskega jezika, slovenska slovarska tradicija, sodobna leksikografija, slovarski koncept

\section{UVOD}

Potem ko je bil konec maja 2013 predstavljen Predlog za izdelavo Slovarja sodobnega slovenskega jezika (Krek, Kosem in Gantar 2013; v nadaljevanju Predlog), se je slovenska strokovna (in laična) javnost ob različnih pogledih na sodobno slovaropisje in leksikografske kompetence razdelila glede tega, ali naj 
novi, tj. sodobni ${ }^{1}$ slovar sodobnega slovenskega jezika, sledi predvsem leksikografski tradiciji, kot se je oblikovala s Slovarjem slovenskega knjižnega jezika (SSKJ), ali naj se od te tradicije oddalji, zlasti v smer slovarskih praks, kot so se $\mathrm{v}$ zadnjih $10-20$ letih uveljavile $\mathrm{v}$ Evropi, ${ }^{2} \mathrm{~s}$ poudarkom na vključevanju jezikovnotehnoloških postopkov $\mathrm{v}$ leksikografski proces. V prispevku želimo ugotoviti, kaj je dejansko mogoče pojmovati kot slovensko leksikografsko tradicijo, v čem se kažejo odstopanja od nje v Predlogu in katere leksikografske rešitve, podprte tako s tradicijo kot inovacijo, bi bilo smiselno upoštevati pri zasnovi novega slovarja.

Pri iskanju odgovorov na zastavljena vprašanja smo upoštevali konceptualna izhodišča, kot so bila predstavljena na strokovnem posvetu o novem slovarju slovenskega jezika leta 2008 (inštitutski posvet 2009),3 in na strokovnem posvetu, ki ga je organiziralo Ministrstvo za kulturo RS leta 2014 (posvet MK 2014), ter konceptualne smernice pri izdelavi Leksikalne baze za slovenščino (LBS), 4 na katerih temelji vsebinska zasnova Predloga. Poleg omenjenega pa še SSKJ, 5 zlasti Uvod in interna navodila redaktorjem ter Uvod v Slovar novejšega besedja slovenskega jezika (SNB), ki po besedah urednikov temelji na tradiciji SSKJ in nakazuje nekatere prvine pripravljajočega se novega razlagalnega

\footnotetext{
${ }_{1}$ Prvi pridevnik sodobni se nanaša na sodobne slovarske prakse, drugi pa na sodobni slovenski jezik, kar je v danih okoliščinah dogovorni pojem.

2 V zvezi z novim slovarjem Inštituta za slovenski jezik Frana Ramovša ZRC SAZU se kot relevanten omenja srednjeevropski prostor (Snoj 2013, 2014: 3). Tak vidik v kontekstu nadaljevanja slovenske slovarske tradicije zagovarja tudi konceptualna naslonitev na slovarje slovanskih jezikov v knjižni obliki (Perdih 2013). V Predlogu zagovarjamo usmeritev slovenske leksikografije v celotni evropski prostor s poudarkom na dobrih slovarskih praksah zadnjih 10 let in z upoštevanjem jezikovnih skupnosti, ki imajo podobno število govorcev kot slovenščina.

3 Dostopno na: http://isjfr.zrc-sazu.si/sl/publikacije/strokovni-posvet-o-novem-slovarjuslovenskega-jezika-23-in-24-oktober-2008\#v (28. 12. 2014).

4 Izdelava LBS je bila ena od aktivnosti projekta Sporazumevanje v slovenskem jeziku (dostopno na: http://www.slovenscina.eu/), ki ga je financirala Evropska unija iz Evropskega socialnega sklada ter Ministrstvo za izobraževanje, znanost in šport RS.

$5 \mathrm{~V}$ času nastajanja prispevka je izšla 2. izdaja SSKJ (SSKJ2), rezultati podrobne analize, zlasti v odnosu do prve izdaje (SSKJ1), so prikazani v prispevku S. Kreka te tematske številke, upoštevali pa smo tudi kritično oceno druge izdaje SSKJ (Ahlin idr. 2014). Ker koncept v drugi izdaji ni bil spremenjen oz. o konceptualnih spremembah v strokovni literaturi ni bilo ničesar napisanega, se v prispevku v zvezi s SSKJ sklicujemo na njegovo 1. izdajo, razen če ne povemo drugače.
} 
slovarja. Odgovore na vprašanja smo iskali tudi v drugih prispevkih, ki se tičejo bodisi sodobnih slovarskih praks bodisi pri zasnovi novega slovarja zagovarjajo tradicionalne vidike.

Primerjava konceptov z vidika slovarske tradicije na eni in inovacij na drugi strani temelji na treh, po našem mnenju temeljnih izhodiščih, ki odražajo razlike v slovarski zasnovi, in sicer (a) slovarski uporabnik, (b) medij in (c) jezikovnotehnološka zasnovanost. Ker se posamezni vidiki med seboj prepletajo in problematike ni mogoče obravnavati izolirano, smo z uporabniškega vidika obravnavali tudi vprašanji zajetja leksike ter oblikovanja pomenskih razlag. $\mathrm{Z}$ vidika medija, $\mathrm{v}$ katerem bo slovar na voljo, smo obravnavali možnost sprotnega posodabljanja podatkov in njihovo organizacijo na ravni slovarske makro- in mikrostrukture, znotraj tega pa razmerje med slovarsko iztočnico in njeno vsebino oz. pomeni. $\mathrm{V}$ prispevku bomo izpostavili tudi pomembnost združevanja leksikografskega procesa $\mathrm{z}$ jezikovnotehnološkim znanjem na primeru avtomatizacije leksikografskih postopkov, ki se v razmerju do tradicionalnih leksikografskih kompetenc pogosto dojemajo posplošeno ali napačno. $\mathrm{V}$ nadaljevanju bomo $\mathrm{v}$ zvezi $\mathrm{s}$ slovarjem, zasnovanem na tradiciji, govorili o inštitutskem oz. akademijskem slovarju, ${ }^{6} \mathrm{v}$ zvezi z jezikovnotehnološko zasnovanim pa o predlaganem oz. korpusnem slovarju. 7

\footnotetext{
${ }^{6} \mathrm{~V}$ zvezi z inštitutskim slovarjem se v odnosu do predlaganega skuša vzpostaviti protipol temeljnega nasproti aplikativnemu slovarju (Snoj 2013; Krvina 2014), čeprav izraza temeljni slovar v evropski leksikografiji ne najdemo. Izraz, ki se v leksikografiji uporablja za podobne slovarje, kot je SSKJ, je morda akademski ali akademijski slovar (ang. scholarly dictionary; prim. de Jong 2014), vendar pa se leksikografska skupnost, zbrana okoli pobude COST: European Network of e-Lexicography (dostopno na: http://www.cost.eu/COST_Actions/isch/Actions/IS1305) zaenkrat strinja le o tem, da tak slovar temelji na sistematično zbranem gradivu. Poimenovanji inštitutski in predlagani slovar uporabljamo izključno za namene tega prispevka.

7 Da bi se ustvaril ustrezen protipol, bi bilo mogoče govoriti tudi o konzorcijskem slovarju, saj predstavlja izdelava koncepta slovarske baze na izhodiščih Predloga prvi skupni projekt Konzorcija za jezikovne vire in tehnologije, ustanovljenega $\mathrm{v}$ okviru istoimenskega centra CJVT (dostopno na: http://cjvt.si/).
} 


\section{SLOVARSKI UPORABNIK}

Uporabnik se pri zasnovi vsakega slovarskega priročnika postavlja kot izhodišče za celo vrsto odločitev, ki bistveno vplivajo na vsebino in izgled končnega izdelka, zato si najprej poglejmo, kako je uporabnik določen v SSKJ, kako v Predlogu in kakšen bi po našem mnenju moral biti odnos do uporabnika pri oblikovanju koncepta za novi slovar slovenskega jezika.

V Uvodu v SSKJ uporabnik ni eksplicitno določen, posredno pa je mogoče razbrati, da je »/p/ojmovni svet, zajet z besediščem slovarja, /.../ predstavljen s stališča sodobnega slovenskega človeka « (SSKJ Uvod: XI; § 10; poudarki so avtoričini) ter da »/r/azlage zajemajo tiste pomenske oz. funkcijske prvine, ki so bistvene za enotno predstavo pojma, gledano s stališča povprečnega uporabnika slovarja« (SSKJ Uvod: XIV; § 41). Predpostavka je, da je povprečni uporabnik ${ }^{8}$ »širokega starostnega razpona«, »nekdo s končano srednjo šolo« (Vidovič Muha 2009: 24) oz. "nekdo z višjim znanjem in višjim zanimanjem « (Humar 2009: 91). Kljub načelnemu strinjanju, da bo novi slovar namenjen uporabnikom in ne piscem ${ }^{9}$ (M. Snoj 2009: 90), je izražena težnja, da mora ohranjati svoj nivo neodvisno od uporabnika, implicitno pa je tudi dojemanje uporabniške prijaznosti kot nečesa, kar slovarju znižuje referenčno vrednost

(J. Snoj 2009: 90):

Treba je razmišljati o uporabniku in zares je zdaj zelo popularno, da se zelo skrbi, da uporabnik ne bi bil preveč podvržen naprezanju, če bi moral kaj pogledati. Ne vem, če je to najboljša pot, če naj se kakšna vsebina predstavi njej ustrezno, da se namreč na prvo mesto daje to, da bo za uporabnika vse popolnoma enostavno. Prav je, da so stvari v slovarju čim bolj enostavne, ker to absolutno pripomore k namenu slovarja. Da bi se pa to merilo zmeraj za vsako ceno dajalo na prvo mesto, preprosto ni potrebno. Slovar, če je premišljen in konsistenten, tudi sam oblikuje uporabnika, ga vzgaja in ga motivira, da se tudi nauči nekaj brati.

\footnotetext{
${ }^{8} \mathrm{Na}$ inštitutskem posvetu (2009) se omenja tudi vsakdanji in navadni uporabnik.

9 Mišljeni so verjetno leksikografi in jezikoslovci.
} 
Pri oblikovanju koncepta za novi slovar slovenskega jezika se moramo najprej zavedati, da se današnji slovarski uporabnik precej razlikuje od uporabnika, ki mu je bil namenjen SSKJ, saj je njegov jedrni del nastajal v 60. in 70. letih, ter da o današnjem (splošnem) slovarskem uporabniku ne vemo veliko. Če je bilo namreč še do nedavnega mogoče verjeti, da si uporabniki ne želijo velikih sprememb, ko se navadijo in udomačijo z določenim slovarjem, se je tehnološka podoba našega vsakdana spremenila $\mathrm{v}$ tolikšni meri, da so se korenito spremenile tudi navade in pričakovanja uporabnikov, zato je po prepričanju avtorice ena prvih nalog pri oblikovanju koncepta sodobnega slovarja slovenskega jezika določiti slovarskega uporabnika (oz. t. i. uporabniške skupine) glede na tip uporabniških problemov in glede na situacije, $\mathrm{v}$ katerih se zateče k slovarju. Splošni uporabnik, ki ga omenjajo udeleženci inštitutskega posveta kot dediščino SSKJ, je v tem trenutku pravzaprav najmanj definiran uporabnik, še posebej, če v skladu s slovarsko tradicijo SSKJ govorimo o "sodobnem človeku «, saj se ta spreminja skladno s časom, v katerem živi. Poleg tega je eno od pomembnih dejstev sodobnega časa, ki se tiče celotne jezikovne skupnosti, pomembnost obstoja jezikovnih opisov, ki jih je mogoče uporabiti tudi za informacijsko-komunikacijsko opremljenost jezika. Zato je smiselno oba vidika medsebojno povezati in uporabnika določiti glede na dvojni namen izrabe slovarske baze: jezikovnotehnološkega in slovarskega. To namensko dvojnost, ki je bila za slovenščino uresničena pri izdelavi LBS, potrjujejo tudi sodobne evropske slovarske in jezikovnotehnološke prakse, ki so se odzvale na potrebo po optimiziranju jezikovnih opisov.

Slovarske opise je z različnimi tehničnimi in oblikovalskimi možnostmi mogoče do neke mere približati diferenciranemu človeškemu uporabniku, vendar pa je bistvena vsebina. Slovarski opis, ki predvideva šolarja ali govorca, ki se slovenščine uči kot tujega jezika, se tako nujno razlikuje od slovarskega opisa, ki predvideva odraslega človeka ali t. i. splošnega uporabnika. Če tega skušamo 
opredeliti čim bolj splošno, ${ }^{10}$ zanj po vsej verjetnosti velja, da je materni govorec slovenščine in da slovar uporablja kot priročnik, tj. za reševanje določene sporazumevalne zagate, manj pa za raziskovanje jezika. Pri tem je stopnja podrobnosti slovarskega opisa seveda ključnega pomena, zato jo je dobro natančneje določiti v slovarski zasnovi in pri tem upoštevati, da podrobneje razčlenjena slovarska informacija zahteva tudi natančnejšo določitev uporabnika. Na podlagi tujih raziskav potreb sodobnega uporabnika (Müller-Spitzer idr. 2011; Prinsloo idr. 2011; Lew 2013; Lew in Deschryver 2014) je mogoče še ugotoviti, da uporabniki od sodobnega slovarja pričakujejo še hitro, enostavno in brezplačno dostopnost, npr. prek različnih digitalnih in mobilnih naprav, ki so jih pri izobraževanju, v svojem poklicnem ali vsakdanjem delu vajeni uporabljati, prilagodljivost vsebin, možnost sprotnega posodabljanja, večpredstavne vsebine in povezave na jezikovne in enciklopedične vire (prim. Gorjanc 2014).

\subsection{Zajetje besedišča}

Čeprav je bil na posvetu MK 2014 sprejet sklep, da bo novi slovar »primeren in ustrezno oblikovan za različne uporabnike«, se zdi, da želi inštitutski slovar naslavljati predvsem kultiviranega splošnega uporabnika, zato je primarno usmerjen v popis leksike slovenskega knjižnega jezika, vsa druga leksika, zajeta $\mathrm{v}$ obsegu, kot ga je določalo gradivo, ${ }^{11}$ pa je z vidika knjižnosti kvalificirana. Ključna konceptualna izhodišča je mogoče po Müllerju (2009: 17) opredeliti takole:

10 Ugotovitve izhajajo iz analize pogostih vprašanj $\mathrm{v}$ obstoječih pravopisnih in drugih svetovalnicah ter na internetnih forumih (prim. Dobrovoljc in Krek 2011: 91), deloma iz analize napak učencev v korpusu Šolar (Kosem idr. 2012).

${ }_{11}$ Čeprav seznam ekscerpiranih del še vedno ni javno na voljo, je iz posameznih objav (prim. Müller 2009: 17) razvidno, da je prevladovalo domače leposlovje, medtem ko so bila denimo publicistična besedila zastopana le v $3 \%$. Poleg tega so publicizmi veljali že v izhodišču za stilno slabe izraze (prim. Vidovič Muha 2009: 21). Korpusno izhodišče, kot ga zastopa predlagani slovar, nasprotno teži $\mathrm{k}$ čim bolj realni proporcionalni uravnoteženosti pisne slovenščine (Logar Berginc idr. 2012). 
- SSKJ je enojezični, srednje velik slovar sodobnega knjižnega jezika.

- Izhodiščni koncept temelji na dejanski rabi zvrstno diferenciranega knjižnega jezika, »kar pomeni, da temelji na funkcionalnosti in frekvenci besed in njihovih lastnostih «.

- SSKJ je bil izdelan na podlagi tiskanih besedil, med katerimi prevladuje beletristika druge polovice 19. in prve polovice 20. stol. ${ }^{12}$

- $\quad$ SSKJ se je leta 1962 začel pripravljati na 2,2 milijona izpisov in bil dokončan pri 4 milijonih izpisov. ${ }^{13}$

- $\quad$ SSKJ pravopisno upošteva prevladujočo rabo, torej prakso. ${ }^{14}$

V Uvodu (X-XI; § 7) lahko še preberemo:

Slovar je informativno-normativen, to pomeni, da je v njem knjižni jezik na široko in objektivno predstavljen z vso množico variant in posebnosti, vendar tako, da je že iz razporeditve gradiva in spremnih opozoril vidna pomembnost in vrednost obravnavanih jezikovnih prvin.

Ter da je »/v/ slovarju zajet besedni zaklad (besede, zveze) in prikazana njegova raba, kakor se kaže v sodobnem slovenskem knjižnem jeziku, to je v obdobju od začetka tega stoletja do 1969 oz. do leta izida posamezne knjige« in da »zajema pojmovni svet sodobnega slovenskega človeka v obsegu 110.000 gesel« (XI; § $10)$.

Časovno gledano lahko torej rečemo, da imamo v SSKJ z enotnim konceptom razumevanja knjižnega jezika opisan jezik prvih 90 let prejšnjega stoletja. $\mathrm{Z}$ izdajo SNB, katerega namen je bil zapolniti časovno vrzel skoraj dveh desetletij, pa se je knjižnojezikovno izhodišče SSKJ spremenilo, saj je v veliko večji meri zajeta publicistika, sleng in strokovni žargon, kar je verjetno v prvi vrsti

\footnotetext{
${ }^{12}$ SSKJ Uvod, XVI; § 2: »Najbolj izčrpno je predstavljen leposlovni jezik izvirne in prevodne literature, ker se v njem najbolj kaže kontinuiranost slovenskega jezika in ker zelo vpliva na vse druge zvrsti knjižnega jezika.«

13 Müller navaja podatke iz Letopisa SAZU (1991 in 1993).

14 Snovalci SSKJ so ob njegovem izidu poudarili, da slovar priznava večobraznost norme, saj je ni mogoče obravnavati samo v razmerju prav - narobe (Suhadolnik in Klopčič 1970: 137; Dobrovoljc 2014: 6; Vidovič Muha 1992).
} 
posledica gradiva, ${ }^{15}$ hkrati pa to tudi ni (vedno) vrednoteno z vidika knjižnosti ali usklajeno s predpisi o standardizaciji (SNB: Uvod k tiskani izdaji). Glede na to, da je učinkovita uporaba SNB povezana s SSKJ, saj se ta nanj neposredno navezuje, hkrati pa odstopa od knjižnonormativne informativnosti, ni vedno jasno, katera izhodišča veljajo oz. katera upoštevati pri interpretaciji slovarskih podatkov. To je prišlo še toliko bolj do izraza pri drugi izdaji SSKJ, ki vključuje tudi besedišče in kvalifikacijo, sprejeto v SNB, hkrati pa tudi oznako »knjižni«, ki jo je sicer SNB namenoma opustil (prim. M. Snoj 2013a). Novi akademijski slovar se bo zato moral odločiti, ali bo skladno s tradicijo SSKJ vztrajal pri knjižnojezikovni leksiki in se tako odrekel npr. številnim slengizmom, ${ }^{16}$ ali pa bo slovarski opis prestavil tudi izven knjižnojezikovne sfere, kot je to nakazal z izdajo SNB in SSKJ2. Ob taki dilemi se zastavlja še vprašanje, na čem bo temeljil opis sodobnega jezika: ali govorimo o opisu jezika na novo, tj. z vidika sodobnega človeka, kot je to veljalo za SSKJ, ali pa bo sodobni pogled na svet v akademijskem slovarju le nadgradnja preteklega?

Če se z vidika razmišljanja, kaj lahko pričakujemo v zvezi z geslovnikom in slovarskimi viri pri načrtovanju akademijskega slovarja, opremo na inštitutski posvet, je glede na danes splošno uveljavljene metode korpusne leksikografije treba izpostaviti tudi vprašanje združevanja tradicionalne, tj. na analizi listkovnega gradiva temelječe metodologije, s korpusno oz. kombiniranje listkovne kartoteke, ki naj bi nadomestila 15 -letno gradivno odsotnost v 80 . in 90. letih (Žele 2009: 42), in problemskih izpisov iz leposlovja (M. Snoj 2009: 81) s korpusnim gradivom. Na nezdružljivost obeh metodologij je na inštitutskem posvetu opozoril že Gorjanc (2009: 43), na posvetu MK 2014 pa Gantar (2014) in Logar (2014), vendar pa je vzroke za prepričanje, da je mogoče

\footnotetext{
15 Primarni vir za izdelavo SNB je bil korpus Nova beseda; o neprimernosti vira za slovarsko delo prim. Logar Berginc (2009: 157).

16 Po mnenju sestavljalcev SSKJ številni izrazi, za katere menijo, da pripadajo slengu, npr. dilati, bluziti, car itd., ne bi zadostili SSKJ-jevskim merilom za vključitev v slovar (Ahlin idr. 2014: 123).
} 
metodi neproblematično združevati, treba iskati $\mathrm{v}$ temeljnem nezaupanju slovenske akademske leksikografije v korpusno jezikoslovje, ${ }^{17}$ posledično pa tudi v neizkoriščenosti postopkov korpusne analize pri izdelavi slovarjev. ${ }^{18}$

Sodobnost v slovar sprejetega besedišča je dogovorni pojem, ki ga določajo jezikovne skupnosti različno glede na časovni domet obstoječih slovarskih opisov in glede na družbeno-politične vidike jezikovne situacije. Sodobnost slovenskega jezika je ob upoštevanju omenjenih izhodišč zato smiselno določiti z zadnjo knjigo SSKJ in z okoliščinami ob nastanku samostojne države.

V Predlogu (2013: 20) je odločitev za sodobni jezik nedvomna. Opis jezika, vključno s sistemom označevanja jezikovne rabe, pa temelji na opazovanju dejanskega pisnega jezika, in sicer tako $\mathrm{v}$ njegovem obstoju kot $\mathrm{v}$ obsegu. Izhodišče za prioritetno obravnavo besedišča predstavlja $\mathrm{v}$ slovenskem prostoru ta hip frekvenčna lista korpusa Gigafida (Logar Berginc idr. 2012) v kombinaciji z natančno in kompleksno statistično obravnavo podatkov iz korpusov Kres, Gos (Verdonik in Zwiter Vitez 2011) in drugih ${ }^{19}$ ter leksikalnih zbirk, ki so na voljo v prostem dostopu oz. pod licenco CC. ${ }^{20}$ Kompleksna obravnava vključuje primerjalne statistike glede na pojavljanje iztočnic po žanrih, obdobjih, prisotnost/odsotnost v različnih bazah, pojavljanje v dodatno zgrajenih podkorpusih, kot so denimo učbeniški podkorpus, specializirani podkorpusi za področja, ki so pomembna $\mathrm{z}$ vidika prehajanja terminologije $\mathrm{v}$ splošno rabo, in podobno. Na tak način bi se zagotovil širši geslovnik in hkrati gradivo za leksikografsko analizo, ki bi ustrezalo konceptualnim izhodiščem slovarja kot celote, vključno $\mathrm{z}$ uporabnikom. Temeljna razlika med knjižnojezikovnim izhodiščem, kot ga narekuje leksikografska tradicija SSKJ,

\footnotetext{
$17 \mathrm{Na}$ inštitutskem posvetu je bilo med drugim izraženo mnenje, da je za slovarsko delo uporaba korpusa prezahtevna in prezamudna (J. Snoj 2009a: 38).

${ }_{18}$ Opis izdelave leksikalne podatkovne zbirke na podlagi korpusne analize je bil za slovenščino objavljen v Gorjanc idr. (2005), vloga korpusa pri postavitvi geselskega članka v enojezičnem slovarju pa v Drstvenšek (2003).

19 Pregledni seznam prostodostopnih korpusov je mogoče najti v orodju NoSke, njihov podrobnejši opis pa v Erjavec (2013).

${ }_{20} \mathrm{Npr}$. Sloleks, Slogovni priročnik, SloWNet itd.
} 
in korpusno zasnovanim predlaganim slovarjem je torej v tem, da predlagani slovar besedišča ne opisuje z vidika knjižnojezikovne norme, ampak predvsem $\mathrm{z}$ vidika komunikacijske vloge. Ali z drugimi besedami: če je SSKJ-jevo izhodišče temeljilo na sprejetju in kvalificiranju besedišča $\mathrm{z}$ vidika knjižnojezikovne informativne normativnosti in $\mathrm{z}$ nalogo bralca ne samo informirati, pač pa tudi kultivirati, se v predlaganem slovarju izbor besedišča kot tudi njegov slovarski opis (in družbenojezikovna vloga) premakne v zajetje sodobne pretežno pisne slovenščine s poudarkom na opisu konotativnih, pragmatičnih ter stilnih lastnosti besedišča, kot izhajajo iz empirično preverljivih komunikacijskih situacij.

\subsection{Pomenski opis}

Teoretična zasnova pomenskih razlag v SSKJ (v večji meri pa je podedovana tudi v SNB in v drugi izdaji SSKJ) temelji na strukturalistični pomenoslovni teoriji, ki projicira stopenjsko oz. hierarhično odvisnostno pomensko konceptualizacijo sveta skozi teorijo sintagme v tip t. i. klasične slovarske razlage, oblikovane po sistemu uvrščevalna pomenska sestavina (UPS), ki je jedrni del zveze in neposredna nadpomenka razlagane besede, in razločevalne pomenske sestavine - RPS v odvisnem delu, ki konkretizirajo pojavnost znotraj skupne nadpomenke, npr. slon je zelo velika žival (UPS) z okloma in trobcem (RPS). ${ }^{21}$

Uporabniški vidik pri izbiri razlagalnih strategij je bil na inštitutskem posvetu 2008 izpostavljen v kontekstu kritičnih odzivov na SSKJ, da je potrebno narediti razlage uporabniku bolj razumljive in upoštevati razlagalne strategije, kot jih pozna t. i. komunikacijski tip slovarja (Vidovič Muha 1999; Krek 2004), ki vključuje situacijske pomenske lastnosti, zlasti torej pragmatiko (Müller 2009: 24; Kržišnik 2009: 55). Pri tem lahko še izpostavimo, da odločitev za tip slovarske razlage $\mathrm{v}$ smislu pomenskosestavinska ali stavčna ne more temeljiti zgolj na skladenjskofunkcijskih lastnostih besed, ampak predvsem na

${ }^{21}$ Povzeto po SSKJ. 
pomenskih.

V Predlogu za novi slovar slovenskega jezika je bilo oblikovanju pomenskih razlag namenjene veliko pozornosti, pri čemer predlagane novosti izhajajo najprej iz sodobne korpusno utemeljene pomenske teorije, kar dejansko predstavlja odmik od SSKJ-jeve tradicije, ter iz dvojne namembnosti slovarske baze, tj. njene jezikovnotehnološke in slovarskopriročniške uporabnosti.

Ko govorimo o na korpusnem pristopu utemeljeni pomenski teoriji, imamo v mislih predvsem teorijo pomenskih shem, izoblikovano pri projektu FrameNet (Filmore 1976; Filmore idr. 2003) ${ }^{22}$ in teorijo jezikovnih konvencij ter možnosti njihove izrabe (ang. Theory of Norms and Exploitations, Hanks 1994), preverjeno v projektu Corpus Pattern Analysis (CPA). ${ }^{23}$ Za oba projekta je značilno, da združujeta jezikovnotehnološko in slovarskopriročniško uporabnost. Poleg omenjenih teoretičnih in metodoloških izhodišč smo pri izdelavi LBS upoštevali tudi razlagalne strategije pri oblikovanju stavčnih definicij, ki so bile realizirane pri slovarskih projektih Collins Cobuilda, kasneje pa preizkušene tudi pri drugih slovarjih in jezikih (prim. Bańko 2010). Ker so bili omenjeni pristopi v slovenski jezikoslovni literaturi že predstavljeni (Krek 2004; Gantar idr. 2009; Šorli 2014), naj na tem mestu povzamemo le tiste razlagalne strategije, ki prinašajo spremembe glede na tradicijo SSKJ.

Bistveno za določanje in opis pomenov v slovarski bazi, ki predstavlja izhodišče za predlagani slovar, je najprej njegova semantična in ne skladenjska orientacija, kot jo npr. zasledimo pri opisu slovničnih in funkcijskih besed $\mathrm{v}$ SSKJ. ${ }^{24}$ Orientacije v pomen (pri čemer so skladenjska opozorila lahko pomenu

\footnotetext{
${ }^{22}$ Izhodiščno je teorija utemeljena na angleščini, vendar je aplicirana tudi na druge jezike. Za slovenščino prim. Može (2013).

23 Opis glagolskih vzorcev (ang. Pattern Dictionary of English Verbs), ki je nastal pri projektu CPA, je dostopen na: http://pdev.org.uk/\#browse? $\mathrm{q}=; \mathrm{f}=\mathrm{C}$.

24 Eden od pokazateljev funkcijskoskladenjske zasnove v SSKJ je denimo izhodiščna urejenost pomenov pri veznikih in zaimkih glede na znotrajstavčno in medstavčno vlogo oz. sklonsko vezavo. Več o tem Gantar (2015: v tisku).
} 
dodana na različne načine) ${ }^{25}$ ne preferira le spletni medij, o čemer več $\mathrm{v}$ samostojnem poglavju, pač pa osredotočenost slovarskega priročnika na pomenske podatke, kar v veliki meri vpliva na njegovo notranjo organizacijo.

Druga stvar, ki je pomembna za oblikovanje pomenskih razlag, kot jih vidimo v novem slovarju, je ločevanje med pomenskim potencialom, ki ga ima beseda $\mathrm{v}$ svojem realnem življenju, tj. zunaj slovarja ali slovarske baze, in leksikografskim opisom pomena, tj. leksikografsko razlago, ki je metaslovarski konstrukt. Zato sta tudi, kot ugotavljata Atkins in Rundell (2008: 263), postopek pomenskega dekodiranja v vsakdanjem jezikovnem komuniciranju in postopek razdvoumljanja pomenov $\mathrm{v}$ slovarjih med seboj neprimerljiva. Podobno je že v 6o. letih razmišljal tudi Bolinger (1965: 556):

Slovarji ne definirajo, temveč pomagajo ljudem razumeti pomen. Če upoštevamo ta namen, je najpomembnejša naloga slovarja ustvariti niz namigov in asociacij, ki bodo povezale znano z neznanim.

in v 70. Fillmore (1976: 32):

Pomen je najbolje interpretirati probabilistično, se pravi v smislu najboljšega približka prototipu in ne v smislu iskanja niza zadostnih ali potrebnih pogojev.

Pri oblikovanju pomenskih opisov v LBS smo oba pristopa vključno $\mathrm{s}$ strategijami oblikovanja stavčnih razlag, izhodiščno uveljavljenih v Collins Cobuildovih slovarjih za učenje angleščine kot tujega jezika, prilagodili specifikam slovenščine (prim. Šorli 2014) v t. i. pomenskih shemah, ki predstavljajo možno izhodišče za oblikovanje stavčnih razlag v sodobnem slovarju slovenskega jezika. Klasična slovarska razlaga ostaja ustrezen tip pomenskega opisa pri razlaganju velike večine konkretnih in abstraktnih samostalnikov oz. samostalniških zvez z ustaljeno pomensko vrednostjo oz. pri vseh tistih pomenih, ki se ne izražajo prek komunikacijske funkcije. V

${ }_{25}$ Ena od pomembnih prednosti posredovanja slovničnih informacij v ločenem razdelku je razbremenitev obvestilno zelo kompleksnega geselskega zaglavja, ki je značilno za knjižni format. 
primerjavi s stavčnimi pa so analitične razlage manj učinkovite pri tistih besedah oz. njihovih pomenih, kjer je integracija skladenjske informacije $\mathrm{v}$ sobesedilo pomembna za ustrezno pomensko interpretacijo. Stavčne razlage je zato smiselno uporabiti vsaj še pri vezljivostnih pomenih samostalnikov in pridevnikov (i) ter povsod tam, kjer konverzacijski obrazec »če ...« stavka omogoča vključitev pragmatičnih in konotativnih pomenskih elementov, pa tudi elementov, ki se tipično realizirajo v govorjenem diskurzu (ii). ${ }^{26}$

\section{(i) posten}

1 postni ČAS je obdobje, ko človek ničesar ne je

1.2 postna JED ali PREHRANA je primerna za čas, ko se človek posti

$1.3 \mathrm{v}$ krščanskem okolju postno OBDOBJE traja 40 dni od konca pusta do velike noči

\section{(ii) cviliti}

z neodobravanjem če rečemo, da GLASBILO cvili, želimo povedati, da oddaja neprijeten zvok, navadno zato, ker kdo ne zna igrati

\section{cepec}

če rečemo komu cepec, ga imamo za neumnega in nepremišljenega

Stavčni tip razlage najbolje vključuje tudi t. i. situacijsko semantiko, kot je razvidna pri nekaterih prislovnih pomenih, in če je raba vezana pretežno na govorjeni diskurz (4. pomen):

\section{mimo}

1. če se predmet ali prevozno sredstvo PREMIKA mimo česa, se navadno hitro približuje in potem oddaljuje, ne da bi se na določeni točki ustavil

3. ko je nek DOGODEK mimo, je stvar preteklosti

4. v neformalnem diskurzu če rečemo, da je neko DEJANJE, RAVNANJE ali IZJAVA mimo, se nam zdi, da je neustrezno ali v določeni situaciji neprimerno Vključevanje stavčnih razlag v pomenski opis pa ni edina novost leksikografije

${ }^{26}$ Primeri so izdelani na podlagi razlagalnih strategij, ki so se oblikovale pri izdelavi LBS. 
zadnjih 30 let, pač pa so s prenosom v spletni medij na voljo tudi drugačni načini navigacije po pomenski strukturi gesla, ki odpira več možnosti kombiniranja pomenskih informacij, boljšo preglednost nad pomensko zgradbo gesla in možnost osredotočenja samo na posamezni pomen besede (Lew 2010). Pri izdelavi sodobnega spletnega slovarja bi bilo tako mogoče kombinirati več nivojev pomenske informacije, kar je bilo za slovenščino že preizkušeno pri izdelavi LBS, ter vključiti možnost osredotočenja na določen tip $\mathrm{v}$ slovar integrirane informacije prek t. i. pomenskega menija oz. s pomočjo pomenskih indikatorjev.

\section{SLOVARSKI MEDIJ}

Vprašanje slovarskega medija postaja $\mathrm{v}$ informacijski dobi in posledično $\mathrm{s}$ prenosom slovarskih vsebin na splet in mobilne aplikacije ključno pri vrsti teoretičnih in metodoloških vprašanj, ki se tičejo leksikografije. V veliki meri je pod vprašaj postavljeno celo dojemanje slovarja kot takega, saj se ta seli v obliko, ki je veliko bolj pretočna, fleksibilna in prilagodljiva kot knjižni format. $\mathrm{Z}$ njo se meje med različnimi tipi jezikovnih priročnikov brišejo, omogočena je interakcija jezikovnih vsebin z elementi izobraževanja, ustvarjalnosti, v proces nastajanja, prikazovanja in deljenja vsebin se bodisi prek družbenih omrežij bodisi neposredno vključuje uporabnik. $\mathrm{S}$ tem ko so slovarji postopoma iz knjige prešli na diskete, $\mathrm{CD}$-je, internetne strežnike in nenazadnje na mobilne naprave, so se znašli, kot pravita Lew in de Schryver (2014: 342), med programsko opremo in orodji, ki omogočajo bolj pragmatično in manj togo ideološko dojemanje slovarjev. Narodnopovezovalna vloga slovarja je v takih okoliščinah po nujnosti postala bolj praktičnojezikovno orientirana, učinkovita uporaba slovarja pa ni več toliko vezana na poznavanje slovarskih zakonitosti (npr. zapisanih v slovarskem uvodu), temveč se povezuje s pojmom digitalne pismenosti. 


\subsection{Posodabljanje slovarskih vsebin}

Sprotno ažuriranje podatkov in takojšnji prenos do uporabnika je eno od konceptualnih izhodišč, ki je neposredno povezano z medijem, za katerega je slovar zasnovan, in hkrati eno od izhodišč, kjer se tradicija in sodobne slovarske prakse razlikujejo. Če izhajamo iz potrebe po zanesljivosti jezikovnih podatkov, ki ne more biti $\mathrm{v}$ nobenem primeru sporna, obstajajo razlike predvsem $\mathrm{v}$ razumevanju tega, kaj zagotavlja podatkom zanesljivost in kaj dejansko pomeni sprotno posodabljanje slovarskih vsebin. Glede prvega je mogoče reči, da je zanesljiv podatek, ${ }^{27}$ če govorimo o sodobnem jeziku, verjetno tak, ki na podlagi jezikoslovno utemeljenih opisov odraža realno jezikovno stanje oz. čim bolj dosledno uresničuje slovarski koncept. Med drugim to pomeni, da je slovar sposoben empirično utemeljiti ter časovno dokumentirati tudi pomenske razširitve ali zožitve, prenos na specializirano področje, pomensko aktualizacijo ipd., ki jo razvijejo posamezne besede v času nastajanja slovarskega opisa. Zato posodabljanje, kot se pogosto interpretira (prim. M. Snoj 2014: 4), ne pomeni spreminjanja odločitev »čez noč« ali celo spreminjanja ali popravljanja jezikoslovnih kategorij, kot so besednovrstne oznake, oblikoskladenjske lastnosti besede ipd., ki izhajajo iz slovarske zasnove, ${ }^{28}$ pač pa predvsem dodajanje informacij, ki uporabniku pomagajo, da besedo ali njen pomen prepozna in rabi na način, ki je v jeziku v aktualnem času običajen in naraven. Take prakse z vidika sodobnih slovarjev, ki so izhodiščno spletno zasnovani, niso novost, ${ }^{29}$ potrjujejo pa dejstvo, da spletne oblike slovarja ni mogoče neproblematično združiti s knjižno zasnovo.

\footnotetext{
${ }_{27}$ Mogoče je sicer špekulirati, kot pravi M. Snoj (2014: 4), da bodo »/j/ezikovni uporabniki slovar sprejeli kot zanesljiv in referenčen priročnik le, če bodo objavljeni podatki ustrezali jezikovni stvarnosti in bodo ostali nespremenjeni v celotnem času njegove primarne uporabe « (poudarila P. G.).

${ }_{28}$ Veliko bolj sporno se nam zdi posodabljanje SSKJ (tj. SSKJ2) z nedokumentiranimi posegi $\mathrm{v}$ sistem kvalificiranja jezikovne rabe, pomenske razlage in razlagalni jezik ter zglede. SSKJ je namreč jezikovni dokument časa, v katerem je nastajal, medtem ko njegova druga izdaja, $\mathbf{s}$ tem ko na eni strani ohranja pomensko členitev in opis, na drugi pa deloma vključuje sodobne poglede na stvarnost, razvojno os zabrisuje (prim. tudi Ahlin idr. 2014).

29 Npr. Sodobni slovar nizozemskega jezika (ANW) in Veliki slovar poljskega jezika, ki sta zasnovana samo za splet.
} 


\subsection{Organizacija slovarskih podatkov}

V tiskanem slovarju so jezikovni podatki običajno razvrščeni na podlagi abecede $\mathrm{v}$ sistem iztočnic in podiztočnic, premik $\mathrm{v}$ digitalno obliko pa je slovarje osvobodil rigidne makrostrukturne ureditve, saj je omogočil različne načine urejanja in dostopanja do želene informacije. Preden si pogledamo razlike, ki jih kažeta izhodiščno knjižna in spletna zasnova slovarja, je potrebno opozoriti, da v času zasnove SSKJ o spletnem mediju še ni bilo mogoče razmišljati, hkrati pa sledenje knjižni zasnovi slovarja pri notranji organizaciji slovarskih podatkov z mislimi na spletno adaptacijo ne more biti uspešno, saj je logično, da drugačen medij po nujnosti zahteva tudi prilagoditev vsebine. S tega vidika predstavljena zasnova akademijskega slovarja, ki predvideva elektronsko slovarsko bazo kot izhodišče in iz nje izhajajočo spletno, elektronsko in knjižno različico (M. Snoj 2014: 2), pri čemer leksikografske rešitve temeljijo na knjižnem mediju, izkazuje nepoznavanje delovanja spletnega medija in vpliva, ki ga ima na notranje strukturiranje podatkov:

Kljub dejstvu, da bodo uporabniki novega slovarja posegali predvsem po njegovi elektronski izdaji, bo ta sestavljen tako, da bo uporaben tudi v knjižni. Naš namen je narediti slovar $\mathrm{v}$ takem obsegu, da bomo lahko sodobno besedje slovenskega jezika prikazali v eni ne preveč debeli knjigi slovarskega formata, in sicer s črkami take velikosti, da jih bo brez očal lahko prebral tudi zmerno daljnoviden uporabnik. Ta namen narekuje gospodarno ravnanje s prostorom, saj besedilo celotnega slovarja skoraj ne bo smelo biti daljše od 12 milijonov znakov, kar je približno polovica obsega SSKJ. Eden od prijemov, kako zastavljeno slovarsko snov našega jezika predstaviti s čim manj znaki, je uvedba sistema podgeselskih iztočnic, pri katerih že sama umestitev pove veliko, dodatne informacije pa se lahko prikažejo na način, ki je gospodarnejši od onega, kot če bi vsak leksem prikazovali v svojem geselskem članku. (M. Snoj 2012: 96)

Leksikografske rešitve, ki se nanašajo na organizacijo znotraj geselske makroin mikrostrukture ter odražajo bodisi SSKJ-jevo tradicijo bodisi leksikografske novosti, povezane s spletno zasnovo, je mogoče opazovati v razmerju med slovarsko iztočnico in njenimi oblikami oz. med slovarsko iztočnico in njeno 
vsebino (pomeni), kamor sodi med drugim zapis osnovne oblike in variantnih oblik na ravni iztočnice, obravnava homonimije ter skladenjske konverzije.

\subsection{Iztočnica - osnovna in variantne oblike}

Slovarske informacije, ki zadevajo variantni zapis iztočnice, npr. skupaj, narazen ali z vezajem, podomačeno ali prevzeto, ter njene oblikoslovne in naglasne posebnosti, dinamični in tonemski naglas ter podatke o izgovoru, se glede na tradicijo knjižnega medija navajajo v zaglavju, npr. v SSKJ:

dán ${ }^{1}$ dnéva m, rod. mn. dní tudi dnévov, daj. mn. stil. dném; daj., or. dv. stil. dnéma; v prislovni rabi:, rod. ed. dné, or. ed. dnévom in dném; rod. mn. dní, tož. mn. dní, mest. mn. dnéh in dnévih; tož. dv. dní tudi dnéva (â ê)

piercing gl. pirsing ${ }^{30}$

$\mathrm{Na}$ inštitutskem posvetu se je v zvezi z obravnavo pisave iztočnic skupaj oz. narazen oz. navajanju dvojničnih oblik, zapisu izgovora in še nekaterim drugim normativnim vprašanjem zastavilo vprašanje, kako se odločati v primerih, ko raba kaže drugačne rešitve, ${ }^{31}$ kot jih predvideva norma (Weiss 2009: 147), še posebej, ker zapis skupaj oz. narazen pri nekaterih zloženkah oz. variantno besednih zvezah vpliva tudi na nepričakovan zapis izgovora. Glede na to, da bi bilo v teh primerih potrebno navesti več variantnih oblik oz. bi uporabnik želel pojasnilo, zakaj do različnih pisnih in izgovornih variant prihaja, je mogoče upravičeno predvidevati, da bi bila informacija za iztočnico oz. zaglavje v tiskani različici preobsežna, kar dobro ponazarja tudi zgornji zgled za samostalnik dan ${ }^{1}$. Podobna dilema se pojavlja v zvezi z zapisom izgovora, kjer se na račun prihranka prostora razmišlja o krčenju podatkov v smislu opuščanja zapisa izgovora pri »neproblematičnih besedah« (Škofic 2009: 139; M. Snoj 2009: 141), o opuščanju fonetičnega zapisa zaradi prezahtevnosti za uporabnika in

\footnotetext{
$3^{30} \mathrm{~V}$ korpusu Gigafida najdemo še piersing in pircing .

${ }^{11}$ V Korpusu Gigafida najdemo poleg 420 zapisov oblike športnorekreacijski, 1.322 zapisov z vezajem in 508 zapisov narazen, kar izpostavlja vsaj dve vprašanji, 1. (ne)ustreznost zapisa skupaj ter 2. učinkovitost dostopa do ustrezne informacije, ki se v SSKJ omejuje le na zapis skupaj.
} 
zaradi nepreglednosti geselskega članka (Škofic 2009: 137).

Da je preobremenjenost geselskega zaglavja $\mathrm{z}$ omenjenimi tipi jezikovnih podatkov $\mathrm{z}$ vidika učinkovitega posredovanja in razumevanja dejansko problem, ki zadeva zanesljivost podatkov in njihovo učinkovito posredovanje, se je pokazalo že ob zasnovi SSKJ, ki je v zvezi s tem iskal rešitev v ločenem navajanju naglasnih paradigem $\mathrm{v}$ shemah $\mathrm{v}$ slovarskem uvodu. $\mathrm{Z}$ ugotovitvijo, da je iskanje podatkov $\mathrm{v}$ takih shemah lahko naporno celo za jezikoslovca (Škofic 2009: 136), se je mogoče v celoti strinjati, zato se zdi tudi smiselno v spletni zasnovi problem reševati v okviru možnosti, ki jih taka oblika ponuja. Ena od rešitev, sicer sprejeta $\mathrm{v}$ več spletno delujočih enojezičnih slovarjev, izpostavljena tudi v Predlogu, je celostna predstavitev tovrstnih podatkov v samostojnih zavihkih. Taka rešitev predvideva prikaz ne le težavnih in pravilnih oblik, pač pa tudi oblik, ki z vidika trenutne norme ali jezikovnosistemske danosti predstavljajo napako in jih zato slovar ne vsebuje, pa tudi neproblematičnih oblik, ki so zanimive $\mathrm{z}$ vidika celostnega prikaza paradigme (npr. za šolsko rabo).

\subsection{Iztočnica v odnosu do pomenov, ki jih zastopa}

Bistvena razlika v pojmovanju iztočnice kot naslovne enote geselskega članka izhaja $\mathrm{v}$ predlaganem slovarju iz dejstva, da njena izhodiščna vloga ni več pomenska, ${ }^{32}$ pač pa predvsem izrazna in da spletna zasnova omogoča usmerjeno dostopanje do posameznih delov gesla, zlasti do pomenov in večbesednih leksikalnih enot. Posledično to pomeni celotno preureditev geselskega članka v smislu ustvarjanja razmerij med naslovno enoto, njenimi oblikami in pomenskimi enotami, ki jih zastopa. Neposredno se to kaže pri zapisu osnovne oblike, pri obravnavi homonimije v odnosu do večpomenskosti, kjer je pomembna tudi načelna odločitev glede sinhronega oz. diahronega pristopa, pri obravnavi skladenjske konverzije in pri obravnavi večbesednih enot. Sledenje tradiciji SSKJ v vseh teh primerih pomeni tudi sledenje logiki

${ }^{2}$ Iztočnice torej ni več mogoče enačiti z leksemom, pač pa le z njegovim izraznim delom. 
knjižnega formata: sem sodi ukvarjanje $\mathrm{z}$ abecedno razvrstitvijo gesel, sistemom indeksiranja homonimov in sistemom podgesel ter varčevanje pri prostoru, ki gre pogosto na račun pomenske informacije in uporabniške prijaznosti. Čeprav so bile kritike SSKJ npr. glede nesamostojne obravnave nekaterih prislovov, pridevnikov ter skladenjskih rab zelo jasne (prim. Gorjanc 2009: 32; Müller 2009a: 34), rešitve, nakazane zlasti v M. Snoj (2012) in SNB $\mathrm{v}$ tem pogledu ne nakazujejo ustreznejših leksikografskih rešitev za novi akademijski slovar.

Osnovni problem, ki izhaja iz sistema podiztočnic, obravnave homonimije in skladenjsko-pomenskega podrejanja stalnih zvez in frazeoloških enot pod iztočnico, je ohranjanje in s tem ugotavljanje večje ali manjše stopnje pomenske odvisnosti besede oz. oblike, ki predstavlja naslovno enoto geselskega članka, do pomenov (in oblik), ki se pod naslovno enoto navajajo. Pregled odločitev glede tega v različnih slovarjih kaže, da rešitev ni ena sama in da so te v veliki meri povezane najprej z obliko, v kateri je slovar na voljo, in s konceptualnimi izhodišči, ki vključujejo bodisi sinhroni bodisi razvojni prikaz pomenske (ne)odvisnosti.

$\mathrm{V}$ tem prispevku, ne da bi tematika prerasla okvire, ne moremo podrobneje govoriti o teoretsko-metodološkem ozadju problematike v celoti, lahko pa z vidika možnega pristopa, ki na račun lažje dostopnosti in boljše razumljivosti ne bi izgubljal na zanesljivosti v slovarju prikazanih podatkov, prikažemo možnost obravnave potencialnih homonimov in skladenjske konverzije.

Da bi ugotovili merila, ki bi jih bilo mogoče čim bolj enoznačno interpretirati pri ločevanju homonimov od večpomenskih besed, se zdi smiselno (Predlog: 74) obravnavati potencialne homonime kot večpomenske: torej kot eno izrazno enoto, ki ji je mogoče pripisati kategorialne lastnosti, ki so značilne za določeno besedno vrsto in so prekrivne za vse (povezane in nepovezane, tj. izhodiščne in prenesene, osnovne in podrejene) pomene, ki jih ta izrazna enota (lema - 
iztočnica) zastopa:33

vila samostalnik

1. zlasti kot odraz premožnosti lastnika lepa, razkošna hiša

2. pravljično ali mitološko bitje

Kot dve izrazni enoti (lemi - iztočnici) in ne kot dva pomena pa je mogoče obravnavati sicer izrazno prekrivne leme, ki nimajo prekrivnega nabora morfosintaktičnih oznak v celotni paradigmi,34 npr. naglas - prislov; naglas samostalnik; moški - pridevnik; moški - samostalnik; prst - samostalnik moškega spola; prst - samostalnik ženskega spola.

Povsod tam, kjer je določitev kategorij odvisna od skladenjskega položaja, npr. pri samostalnikih $\mathrm{v}$ pridevniški vlogi (celofan papir) in obratno (obravnava brezposelnih) ali od komunikacijskih dejavnikov in okoliščin, kot npr. v primeru "členkovnega" obnašanja nekaterih prislovov ali samostalnikov (zdravo!, hvala!), pa tudi predlogov (npr. v razmerju do prislovov), povedkovnikov itd., pa je smiselno govoriti o skladenjski konverziji in jo leksikografsko obravnavati pod eno izrazno enoto, lahko kot samostojni pomen ali/in z opozorilom na tipičen skladenjski položaj ali funkcijo:

pričakovan pridevnik

1 predviden ali predvidevan

1.2 to, kar se predvideva

doseči pričakovano - uporablja se kot samostalnik

2 na katerega čakamo

Da pa ne pride do skušnjave, kjer bi bilo z leksikografskega vidika mogoče kot večpomenskost obravnavati tudi vse $\mathrm{z}$ osnovnimi izrazno prekrivne stranske

\footnotetext{
33 Povsod tam torej, kjer so kategorije določljive z jezikoslovnimi (jezikovnosistemskimi) lastnostmi.

34 Pri morfosintaktičnem označevanju korpusa se je smiselno odločiti za oznako, ki ne vključuje kategorij, ki jih račualnik ne uspe razdvoumiti oz. v zadovoljivem obsegu ustrezno prepoznati. V slovarskem opisu je take oznake mogoče spremeniti na podlagi leksikografove analize in jih v slovar vključiti v obliki opozoril na določene slovnične in skladenjske posebnosti ali posebnosti $\mathrm{v}$ rabi.
} 
besedne oblike, je v ločevanje homonimije od večpomenskosti smiselno priključiti tudi glasoslovna oz. morfonološka merila. Če želi slovar vključevati tudi podatke o naglasu in izgovoru ter o posebnostih, ki se nanašajo zgolj na posamezno obliko, je zato smiselno iz večpomenskosti izločiti tudi izrazno prekrivne leme, ki nimajo v celoti prekrivne paradigme (i), oz. ta ni prekrivna $\mathrm{v}$ naglasnem mestu (ii):

(i) pasti: padem, padeš, pade ... pasti: pasem, paseš, pase ...

(ii) částiti: částim, částiš, části ... častíti: častím, častíš, častí

\section{JEZIKOVNOTEHNOLOŠKA OZ. KORPUSNA ZASNOVANOST SLOVARJA}

Izhodiščne jezikovnotehnološke zasnovanosti slovarja (prim. Fišer 2014) ne moremo obravnavati primerjalno s tradicijo SSKJ, saj se je o vključitvi računalniških metod $\mathrm{v}$ proces nastajanja slovarja oz. slovarskih baz začelo $\mathrm{v}$ resnici govoriti šele v 80. letih, vsekakor pa s postopnim vključevanjem korpusne metodologije v leksikografijo.

Kljub načelnim izjavam, da si izdelave sodobnega slovarja slovenskega jezika brez korpusa ni mogoče zamisliti, je hkrati očitno, da temeljno nezaupanje v računalniški doprinos $\mathrm{k}$ leksikografskemu delu izhaja predvsem iz nepoznavanja možnosti optimiziranja leksikografskega dela na tej podlagi in posledično $\mathrm{v}$ pavšalnih ugotovitvah, da leksikografovega dela računalnik ne more nadomestiti. Zato je pri snovanju slovarja sodobnega slovenskega jezika potrebno pojasniti ključni nesporazum, ki izhaja iz uporabe računalniških možnosti pri oblikovanju slovarja in opozoriti na dejstvo, da neizkoriščanje potencialov, ki jih omogočajo jezikovnotehnološka znanja, pomeni tudi neracionalno porabo denarnih sredstev, kot tudi človeških virov.

Ko govorimo o optimizaciji leksikografskega dela, moramo najprej opozoriti, da 
to ne pomeni hkrati, kot se pogostokrat rado prikazuje, tudi manjše kakovosti leksikografskega opisa. Gre predvsem za to, da je mogoče računalniške zmogljivosti povsod tam, kjer presegajo človeške, smiselno uporabiti za to, da se razbremeni leksikografovo delo tam, kjer ga računalnik ne more nadomestiti. $\mathrm{V}$ prvi vrsti to pomeni premišljeno uporabo orodij za korpusno analizo in predpripravo podatkov, ki omogočajo zanesljivo leksikografsko interpretacijo.

Naj na tem mestu omenimo le avtomatsko luščenje kolokacij (tudi večbesednih zvez in terminov), ki je bila na slovenskem gradivu že opravljena (Kosem idr. 2013) in je kljub temu, da obstajajo še številne možnosti izboljšanja, že prinesla obetavne rezultate. Pri izdelavi LBS je bila tako izdelana različica slovnice besednih skic (Krek 2012), ki je omogočila luščenje kolokacijskih podatkov, ki predstavljajo dobro osnovo za nadaljnje leksikografsko delo. S tem, ko smo leksikografa opremelili s sežetkom jezikovnih situacij, prepoznanih v leksikalno relevantnih besedilnih kontekstih, skladenjskih strukturah in vzorcih, smo omogočili, da se koncentrira na pomensko členitev in pomenski opis, ne da bi moral ročno pregledovati obsežno količino korpusnih konkordanc, kjer je domala nemogoče prepoznati principe jezikovnega vzorčenja, ki imajo neposredne posledice na leksikalno obnašanje jezika.

Uporaba orodij, kot je npr. Sketch Engine (Kilgarriff idr. 2004), je pri tem nepogrešljiva, kot je tudi jasno, da so nujno potrebne prilagoditve orodja na specifike slovenščine in ustrezna predpriprava korpusa ter njegova obsežnost. $\mathrm{S}$ tem zavedanjem je bilo ob slovnici besednih skic tako za slovenščino kot za postopek avtomatizacije prilagojeno orodje za prepoznavanje dobrih slovarskih zgledov GDEX (Kosem idr. 2011; 2013), ki jih je mogoče v leksikografskem procesu nadgraditi v slovarske. Ob tem je potrebno poudariti, da so bile vse prilagoditve orodij za avtomatizacijo izdelane in večkrat preverjene na podlagi predhodnih ročnih leksikografskih analiz in ugotovitev. Tako je bil učni korpus zgledov, na katerem se je učilo orodje GDEX za slovenščino, izbran na podlagi leksikografskih odločitev, ki pa so sledile jasnim navodilom, kaj velja prepoznati kot dober korpusni in kasneje slovarski zgled. Prav tako je različica 
slovnice besednih skic, ki smo jo uporabili za avtomatsko luščenje podatkov, temeljila na predhodni registraciji skladenjskih struktur, ki so jo leksikografi opravili na podlagi ročne analize pri izdelavi gesel. Posamezne nastavitve parametrov, ki so ključne za to, da leksikograf lahko izpelje zanesljive zaključke na podlagi izluščenih podatkov, so bile $\mathrm{v}$ procesu večkrat testirane in prilagojene, pri tem pa so bile implementirane spremenljivke, kot je npr. besedna vrsta leme ter njena pogostnost $\mathrm{v}$ korpusu, statistična vrednost, ki odloča o stopnji kolokabilnosti kolokatorja, statistična opaznost skladenjske strukture, ki je v podstavi kolokacije, ipd.

Konkretni eksperiment, ki sicer potrebuje usmerjeno evalvacijo primerjave končanega gesla na podlagi ročne analize in na podlagi analize avtomatsko izluščenih podatkov, je nakazal možnosti uporabe jezikovnotehnoloških znanj $\mathrm{v}$ primerih, kjer leksikograf izgublja dragoceni čas in energijo $\mathrm{s}$ selekcioniranjem relevantnih podatkov od nerelevantnih ter $\mathrm{s}$ prenašanjem izbranih kolokatorjev in ustreznih zgledov v slovarski program oz. bazo. Čeprav vedno obstaja bojazen, da bo leksikograf na ta način prikrajšan za uvid v celotno jezikovno situacijo, posledično pa v slovarju ne bo mogoče najti nekaterih pomembnih jezikovnih informacij oz. te ne bodo dovolj natančne (prim. Krvina 2014: 80), je tako možnost treba vzeti v zakup še toliko bolj, če je leksikograf vržen $\mathrm{v}$ morje neselekcioniranih jezikovnih podatkov, iz katerih lahko le $\mathrm{v}$ omejenem obsegu sklepa o splošno veljavnih jezikovnih vzorcih.

\section{SKLEP}

Ključne razlike med tradicionalnim knjižnojezikovno zasnovanim in sodobnim korpusnim oz. jezikovnotehnološko zasnovanim slovarjem se kažejo najprej v odnosu do uporabnika oz. glede na to, kako dojemata svojo družbeno vlogo, znotraj tega pa v zajetju besedišča glede na časovni obseg, družbeni oz. kulturni status jezika in glede na medij, $\mathrm{v}$ katerem je na voljo uporabnikom.

Temeljni lastnosti besedišča, zajetega v SSKJ, sta njegovo knjižnojezikovno izhodišče in informativna-normativnost. Če bi novi slovar želel ohraniti vlogo 
referenčnega slovarja in hkrati ohranjati svojo uporabnost, bi bilo potrebno ponovno premisliti, kje so $\mathrm{v}$ novih okoliščinah meje knjižnega jezika in kaj dejansko pomeni informativnost slovarja.

Korpusno izhodišče predlaganega slovarja na drugi strani predvideva zajetje besedišča v obsegu, ki je realno zastopano $\mathrm{v}$ pisni produkciji, v zvezi z njim pa podati informacije o rabi, slovničnih, stilističnih in drugih lastnostih, ki jih uporabniki potrebujejo za učinkovito jezikovno produkcijo in interpretacijo oz. za učinkovito sporazumevanje. $V$ idealnem primeru bi tak opis predstavljal čim obsežnejši nabor standardnih leksikalnih enot in njihovih pomenov ter nabor standardnih vzorcev jezikovnega obnašanja. Opis jezikovnega standarda bi tako vključeval pravila oz. napotke, utemeljene na empiričnih podatkih, povsod tam, kjer bi bilo z vidika poenotenega obnašanja jezikovnih uporabnikov to smiselno in mogoče.

Čeprav je mogoče predvidevati, da bi bila večina besedišča $v$ knjižnem in neknjižnem slovarju prekrivna, ostajajo razlike predvsem $\mathrm{v}$ tem, kakšno vlogo/nalogo ima slovar pri jezikovnem opisu v odnosu do uporabnika oz. širše jezikovne skupnosti. Očitno je, da želi akademijski slovar ohranjati tradicijo jezikovne kultivizacije, ki pa se ne kaže le v izbiri besedišča, ampak tudi v izbiri metajezika in metajezikovnih podatkov, ki zahtevajo poznavanje slovarskih strategij, od uporabnikov pa določeno jezikoslovno znanje. Priključitev jezikovnotehnološke skupnosti tako $\mathrm{v}$ proces nastajanja slovarja kot $\mathrm{z}$ vidika uporabnosti leksikografsko interpretiranih podatkov pomeni na drugi strani jezikovnotehnološko zasnovan spletni slovar, katerega podatke je mogoče uporabiti pri razvoju IKT za slovenščino, pri posredovanju podatkov uporabnikom pa izkoristiti oblikovalne možnosti spletnega medija, ki jih uporabniki pričakujejo. Dobro je, če je tak slovar zasnovan na jezikovnih virih, ki ne le da odražajo realno stanje v jeziku, pač pa jih je mogoče računalniško procesirati in optimizirati za usmerjeno leksikografsko analizo.

Kot kažejo novejše študije, ki se ukvarjajo z analizo slovarskih uporabnikov, 
ostaja informacija o pomenu to, kar slovarske uporabnike še vedno najbolj zanima (Lew 2010: 290). Čeprav se ta pogled, ki je v skladu s tradicionalno podobo slovarja kot repozitorija besednih pomenov, do danes ni dosti spremenil, je rastoča vloga elektronskih slovarjev korenito spremenila leksikografski pristop k obravnavi in predstavitvi pomena. Kot ugotavlja Lew (2010: 291), je elektronski medij vplival predvsem na preseganje tradicionalne verbalne orientacije $\mathrm{v}$ leksikografiji, tj. na razlaganje besed $\mathrm{z}$ besedami, $\mathrm{z}$ vključevanjem statične in animirane grafike, zvočnih in vizualnih posnetkov pa je vplival tudi na preoblikovanje slovarskega opisa pomena in na pojmovanje osnovne slovarske enote.

Osnovna slovarska enota je postala pomen, za pomensko razlago, ki skuša zajeti jezikovno situacijo tako v slovničnem kot tudi situacijskem kontekstu, pa je pomembno, da se zaveda svoje metaslovarske vloge in da enakovredno združuje notranje jezikovne (leksikalne in skladenjske), kot tudi zunajjezikovne, pragmatične lastnosti pomena. Združevanje razlagalnih pristopov, npr. klasičnoslovarskega in komunikacijskega, se zato kaže kot leksikografska praksa (Rundell 2006), ki omogoča optimalno pomensko obvestilnost tudi v novem slovarju.

Lastnosti spletnega medija se pri vseh izpostavljenih elementih slovarja kažejo kot izredno pomembne, posebej pa je treba izpostaviti možnost nadgrajevanja oz. posodabljanja informacij $\mathrm{v}$ slovarju, organizacijo podatkov na ravni slovarske makro- in mikrostrukture ter avtomatizacijo postopkov, saj gre tudi v teh primerih za prevrednotenje teoretičnih konceptov, sicer poznanih iz klasičnih tiskanih slovarjev.

Sprotno posodabljanje informacij kot ena od uporabniških zahtev, ki jih omogoča sodobni medij, pomeni organizirano spremljanje leksikalnih sprememb ob redni nadgradnji korpusov in njihovo vključevanje bodisi $\mathrm{v}$ obstoječe slovarske informacije bodisi z dodajanjem novih slovarskih enot. Posredovanja aktualne informacije uporabniku že v času njenega nastanka in $\mathrm{z}$ 
ustrezno dokumentacijo zato ni mogoče dojemati kot slovarske nezanesljivosti, kot se pogosto prikazuje, je pa na tak način mogoče ohranjati zadovoljiv obseg in nivo jezikovnega opisa, ki ga jezikovna skupnost najbolj potrebuje.

Kar se tiče organizacije slovarskih podatkov znotraj slovarske zgradbe, je jasno, da knjižno in spletno izhodišče ne moreta predstavljati uspešne integracije, saj je logično, da drugačen medij po nujnosti zahteva tudi prilagoditev vsebine. Premik v dojemanju iztočnice kot izrazne, njenih pomenov pa kot leksikalnih enot se kaže v izključno na sinhronih jezikovnih podatkih utemeljenem obravnanju homonimije $\mathrm{v}$ primerih, ko ni mogoče isti obliki v vseh njenih (tudi etimološko nepovezanih) pomenih pripisati prekrivih jezikovnih kategorij in enotne oblikoskladenjske oz. oblikonaglasne paradigme. In na drugi strani v obravnavanju večpomenskosti $\mathrm{v}$ vseh drugih situacijah, kjer prihaja do prekrivanja oblik znotraj enotno opredeljenih slovničnih in skladenjskih kategorij.

Nenazadnje je tu še jezikovnotehnološka zasnovanost slovarja in vključevanje jezikovnotehnološkega inžiniringa v vse elemente slovarskega nastajanja, tj. od priprave jezikovnih podatkov za leksikografsko analizo do njihove obdelave $\mathrm{v}$ slovarski bazi in prenosa na splet. Brez možnosti strojne procesljivosti podatkov pri nastajanju sodobnega slovarja ni mogoče razmišljati o razbremenitvi slovarskega dela in vpeljavi računalniških zmogljivosti povsod tam, kjer je to mogoče in smiselno. Nekaj takih postopkov, kot je denimo avtomatsko luščenje kolokacijskih podatkov in korpusnih zgledov iz korpusa ter njihov prenos $\mathrm{v}$ slovarsko bazo, je bilo za slovenščino že preizkušenih, dobri rezultati ob sicer številnih prepoznanih možnostih izboljšave pa postavljajo pred sodobno slovensko leksikografsko prakso nove izzive.

Za konec je potrebno opozoriti še na eno pomembno dejstvo. Če je bilo ugotovljeno, da je SSKJ z uresničitvijo svojega koncepta v slovenski prostor prinesel ključna spoznanja evropskega jezikoslovja tistega časa ter opozoril na 
pomembnost interdisciplinarnega pristopa,35 je mogoče zaključiti, da upoštevanje spremenjene slovarske vloge v smislu zajetja, interpretacije in prikaza slovarskih podatkov po nujnosti odraža tudi drugačne metodološke in teoretične pristope ter tako pomeni nadaljevanje SSKJ-jeve tradicije in ne odstopanja od nje. Inovacije, ki jih v odnosu do slovenske leksikografske tradicije predlagamo za spletni slovar sodobnega slovenskega jezika, so tako enako pomembne, kot so bile v času zasnove SSKJ na sodobnih jezikoslovnih spoznanjih utemeljene slovarske strategije. Dosledna izpeljava take zasnove pa ima enak namen, kot ga je imela svoj čas pri SSKJ - tj. izdelavo slovarja, ki bo svojo (sicer glede na SSKJ spremenjeno) družbeno vlogo opravljal enako dobro, kot jo je za svoj čas SSKJ.

\section{LITERATURA}

Ahlin, M., Lazar, B., Praznik, Z. in Snoj, J. (2014): Slovar slovenskega knjižnega jezika. Druga, dopolnjena in deloma prenovljena izdaja. Izdali Slovenska akademija znanosti in umetnosti, Znanstvenoraziskovalni center Slovenske akademije znanosti in umetnosti, Inštitut za slovenski jezik Frana Ramovša. Ljubljana: Cankarjeva založba, 2014. 1. knjiga 1152 str., 2. knjiga 1150. str. Jezik in slovstvo, 59 (4): 121-127.

Atkins, B. T. S. in Rundell, M. (2008): The Oxford Guide to Practical Lexicography. Oxford: Oxford University Press.

Bańko, M. (2010): The Polish Cobuild and its Influence on Polish Lexicography. V: G.-M. de Schryver (ur.): A Way with Words: Recent Advances in Lexical Theory and Analysis. A Festschrift for Patrick Hanks: 323-332. Kampala: Menha Publishers.

Bolinger, D. (1965): The atomization of meaning. Language, Vol. 41, No. 4: $555-573$.

35 Takrat sicer v kontekstu povezovanja slovenistike z drugimi področji znotraj humanistike (Vidovič Muha 2014). 
de Jong, G. (2014): Report on a survey of European dictionaries. The first ENeL workshop in Bled 29-30. September 2014. Dostopno prek: http://www.elexicography.eu/wp-content/uploads/2014/11/Bled-2014-enel_deJong.ppsx (28. 12. 2014).

Dobrovoljc, H. (2014): Normativna informacija v slovarju. V: S. Bergoč in I. Grahek (ur.): Novi slovar za 21. stoletje: E-zbornik prispevkov s Posveta o novem slovarju slovenskega jezika na Ministrstuu za kulturo 12. 2. 2014, Ljubljana, april 2014: 15 str. Ljubljana: Ministrstvo za kulturo.

Dobrovoljc, H. in Krek, S. (2011): Normativne zadrege - empirični pristop. V: Kranjc, S. (ur.): Meddisciplinarnost $v$ slovenistiki (Obdobja, Simpozij, = Symposium, 30): 89-97. Ljubljana: Znanstvena založba FF.

Drstvenšek, N. (2003): Vloga besedilnega korpusa pri postavitvi geselskega članka v enojezičnem slovarju. Jezik in slovstvo, 48 (5): 65-81.

Erjavec, T. (2013): Korpusi in konkordančniki na strežniku nl.ijs.si. Slovenščina 2.o, 1 (1): 24-49.

Fillmore, Ch. J., Johnson, Ch. R. in Petruck, M. (2003): Background to Framenet. International Journal of Lexicography, 16 (3): 235-250.

Fillmore, Ch. J. (1976): Frame semantics and the nature of language: Annals of the New York Academy of Sciences. Conference on the Origin and Development of Language and Speech, 280: 20-32.

Fišer, D. (2014): Vloga jezikovnih tehnologij pri zasnovi slovarja. V: S. Bergoč in I. Grahek (ur.): Novi slovar za 21. stoletje: E-zbornik prispevkov s Posveta o novem slovarju slovenskega jezika na Ministrstvu za kulturo 12. 2. 2014, Ljubljana, april 2014: 13 str. Ljubljana: Ministrstvo za kulturo.

Gantar, P. (2015): Vezniški in predložni pari v jezikovnih priročnikih glede na pomensko-skladenjske lastnosti in rabo. V: H. Dobrovoljc in P. Weiss 
(ur.): Pravopisna razpotja (v tisku).

Gantar, P. (2014): Moč in nemoč korpusnega pristopa k analizi pomenov. V: S. Bergoč in I. Grahek (ur.): Novi slovar za 21. stoletje: E-zbornik prispevkov s Posveta o novem slovarju slovenskega jezika na Ministrstvu za kulturo 12. 2. 2014, Ljubljana, april 2014: 14 str. Ljubljana: Ministrstvo za kulturo.

Gantar, P., Grabnar, K., Kocjančič, P., Krek, S., Pobirk, O., Rejc, R., Šorli, M., Šuster, S. in Zaranšek, P. (2009): Specifikacije za izdelavo leksikalne baze za slovenščino: standard za izdelavo posamezne leksikalne enote $v$ leksikalni bazi. Projekt »Sporazumevanje v slovenskem jeziku « ESS in MŠS̆.

Gorjanc, V. (2014): Slovar slovenskega jezika v digitalni dobi. V: S. Bergoč in I. Grahek (ur.): Novi slovar za 21. stoletje: E-zbornik prispevkov s Posveta o novem slovarju slovenskega jezika na Ministrstvu za kulturo 12. 2. 2014, Ljubljana, april 2014: 12 str. Ljubljana: Ministrstvo za kulturo.

Gorjanc, V. (2009): razprava. V: A. Perdih (ur.): Strokovni posvet o novem slovarju slovenskega jezika, 23. in 24. oktober 20o8. Ljubljana: Založba ZRC SAZU, ZRC SAZU.

Gorjanc, V., Krek, S. in Gantar, P. (2005): Slovenska leksikalna podatkovna zbirka. Jezik in slovstvo, 50 (2): 3-19.

Hanks, P. (1994): Linguistic norms and pragmatic exploitations, or why lexicographers need prototype theory and vice versa. V: F. Keifer, G. Kiss in J. Pajzs (ur.): Papers in Computational Lexicography. Complex '94. Budapest: Hungarian Academy of Sciences.

Humar, M. (2009): razprava. V: Perdih, A. (ur.): Strokouni posvet o novem slovarju slovenskega jezika, 23. in 24. oktober 20o8. Ljubljana: Založba ZRC SAZU, ZRC SAZU. 
Inštitutski posvet (2009): Strokovni posvet o novem slovarju slovenskega jezika, 23. in 24. oktober 20o8. A. Perdih (ur.). Ljubljana: Založba ZRC, ZRC SAZU.

Kilgarriff, A., Rychlý, P., Smrz, P. in Tugwell, D. (2004): The Sketch Engine. V: G. Williams in S. Vessier (ur.): Proceedings of the Eleventh EURALEX International Congress, EURALEX 2004 Lorient, France July 6-10, 2004: 105-116. Lorient: Universite de Bretagne - sud.

Kosem, I., Gantar, P. in Krek, S. (2013): Automation of lexicographic work: an opportunity for both lexicographers and crowdsourcing. V: I. Kosem, J. Kallas, P. Gantar, S. Krek, M. Langemets in M. Tuulik (ur.): Electronic lexicography in the 21st century: thinking outside the paper. Proceedings of the eLex 2013 conference, 17-19 October 2013, Tallinn, Estonia: 32-48. Ljubljana/Tallinn: Trojina, Institute for Applied Slovene Studies/Eesti Keele Instituut.

Kosem, I., Husák, M. in McCarthy, D. (2011): GDEX for Slovene. V: I. Kosem in K. Kosem (ur.): Electronic Lexicography in the 21st Century: New applications for new users. Proceedings of eLex 2011, Bled, 10-12 November 2011: 151-159. Ljubljana: Trojina, zavod za uporabno slovenistiko.

Kosem, I., Stritar, M., Može, S., Zwitter Vitez, A., Arhar Holdt, Š. in Rozman, T. (2012): Analiza jezikovnih težav učencev: korpusni pristop (Zbirka Sporazumevanje). 1. izd. Ljubljana: Trojina, zavod za uporabno slovenistiko.

Krek, S. (2012): New Slovene sketch grammar for automatic extraction of lexical data. SKEW3, Brno, Češka, 21-22. marec 2012. Dostopno na: https://trac.sketchengine.co.uk/attachment/wiki/SKEW-3/Program/Krek_SKEW3.pdf?format=raw (28. 12. 2014).

Krek, S. (2004): Slovarji serije COBUILD in formalizacija definicijskega 
jezika. Jezik in slovstvo, 49 (2): 3-16.

Krek, S., Kosem, I. in Gantar, P. (2013): Predlog za izdelavo Slovarja sodobnega slovenskega jezika. Izd. 1.1. Dostopno na: http://www.sssj.si/ (28. 12. 2014).

Kržišnik, E. (2009): razprava. V: A. Perdih (ur.): Strokovni posvet o novem slovarju slovenskega jezika, 23. in 24. oktober 2008. Ljubljana: Založba ZRC SAZU, ZRC SAZU.

Krvina, D. (2014): Poročilo z oceno o srečanju ENeL COST (29.-30. 9. 2014) na Bledu. Slovenščina 2.o, 2 (1): 76-86. (v tisku). Dostopno na: http://www.trojina.org/slovenscina2.o/arhiv/2014/1/Slo2.o_2014_1_06.pdf. (28. 12. 2014)

Lew, R. (2013): From paper to electronic dictionaries: Evolving dictionary skills. V: D. Kwary, N. Arnos, W. Musyahda in L. Musyahda (ur.): Lexicography and Dictionaries in the Information Age. Selected papers from the 8th ASIALEX international conference: 79-84. Surabaya: Airlangga University Press.

Lew, R. (2010): Multimodal Lexicography: The Representation of Meaning in Electronic Dictionaries. Lexikos, 20: 290-306.

Lew, R. in de Schryver G.-M. (2014): Dictionary users in the digital revolution. International Journal of Lexicography, 27 (4): 341-359.

Logar Berginc, N. Grčar, M., Brakus, M., Erjavec, T., Arhar Holdt, Š. in Krek, S. (2012). Korpusi slovenskega jezika Gigafida, KRES, ccGigafida in ccKRES: gradnja, vsebina, uporaba. Ljubljana: Trojina, zavod za uporabno slovenistiko; Fakulteta za družbene vede.

Logar, N. (2014): Verodostojnost korpusov kot gradivnega vira za slovar. V: S. Bergoč in I. Grahek (ur.): Novi slovar za 21. stoletje: E-zbornik prispevkov s Posveta o novem slovarju slovenskega jezika na Ministrstvu za kulturo 12. 2. 2014, Ljubljana, april 2014: 15 str. 
Ljubljana: Ministrstvo za kulturo.

Logar, N. (2009): O dveh znanstvenomonografskih leksikalnih seznamih. A. Gložančev, P. Jakopin, M. Michelizza, L. Uršič in A. Žele: Novejša slovenska leksika (v povezavi s spletnimi jezikovnimi viri). Ljubljana: Založba ZRC, ZRC SAZU, 2009. 408 str. Jezik in slovstvo 54 (3-4): 153159.

Može, S. (2013): FrameNet in večjezičnost: kontrastivna analiza glagolov premikanja $v$ slovenščini in angleščini. Doktorska disertacija. Mentor Dušan Gabrovšek, somentor Rastislav Šuštaršič. Univerza v Ljubljani: Filozofska fakulteta.

Müller, J. (2009): Kritične misli in zamisli o SSKJ. V: A. Perdih (ur): Strokovni posvet o novem slovarju slovenskega jezika, 23. in 24. oktober 20o8: 17-25. Ljubljana: Založba ZRC, ZRC SAZU.

Müller, J. (2009a): razprava. V: A. Perdih (ur.): Strokovni posvet o novem slovarju slovenskega jezika, 23. in 24. oktober 20o8. Ljubljana: Založba ZRC SAZU, ZRC SAZU.

Müller-Spitzer, C., Koplenig, A. in Töpel, A. (2011): What Makes a Good Online Dictionary? - Empirical Insights from an Interdisciplinary Research Project. V: I. Kosem in K. Kosem (ur.): Electronic Lexicography in the 21st Century: New applications for new users. Proceedings of eLex 2011, Bled, 10-12 November 2011: 203-208. Ljubljana: Trojina, zavod za uporabno slovenistiko.

Perdih, A. (2013): Tipologija slovanskih enojezičnih slovarjev. Doktorska disertacija. Mentor Marko Snoj, somentorica Andreja Žele. Univerza v Ljubljani: Filozofska fakulteta.

Posvet MK (2014): Novi slovar za 21. stoletje: E-zbornik prispevkov s Posveta o novem slovarju slovenskega jezika na Ministrstvu za kulturo 12. 2. 2014, Ljubljana, april 2014. S. Bergoč in I Grahek (ur.). Ljubljana: 
Ministrstvo za kulturo.

Prinsloo, D. J., Heid, U., Bothma, Th. in Faaß, G. (2011): Interactive, dynamic electronic dictionaries for text production. V: I. Kosem in K. Kosem (ur.): Electronic Lexicography in the 21st Century: New applications for new users. Proceedings of eLex 2011, Bled, 10-12 November 2011: 215-220. Ljubljana: Trojina, zavod za uporabno slovenistiko.

Rundell, M. (2006): More than one way to skin a cat: why full-sentence definitions have not been universally adopted. V: E. Corino, C. Marello in C. Onesti (ur.): Proceedings of the Twelfth EURALEX International Congress: 323-337. Turín: Accademia della Crusca, Università di Torino.

SNB: Slovar novejšega besedja slovenskega jezika (2013). M. Snoj in A. Bizjak Končar (ur.). Ljubljana: Založba ZRC, ZRC SAZU.

Snoj, J. (2009): razprava. V: Perdih, A. (ur.): Strokovni posvet o novem slovarju slovenskega jezika, 23. in 24. oktober 20o8. Ljubljana: Založba ZRC SAZU, ZRC SAZU.

Snoj, J. (2009a): Novi slovar: spodbuda za posodobitev slovenskega slovaropisja. V: A. Perdih (ur): Strokovni posvet o novem slovarju slovenskega jezika, 23. in 24. oktober 20o8: 37-45. Ljubljana: Založba ZRC, ZRC SAZU.

Snoj, M. (2014): Objavne oblike novega slovarja slovenskega jezika. V: S. Bergoč in I. Grahek (ur.): Novi slovar za 21. stoletje: E-zbornik prispevkov s Posveta o novem slovarju slovenskega jezika na Ministrstvu za kulturo 12. 2. 2014, Ljubljana, april 2014: 5 str. Ljubljana: Ministrstvo za kulturo.

Snoj, M. (2013): “SSKJ danes in jutri, potem pa ...”. Delo, Sobotna priloga, 21. 9. 2013. Dostopno prek: http://www.delo.si/zgodbe/sobotnapriloga/sskjdanes-in-jutri-potem-pa-hellip.html (28. 12. 2014). 
Snoj, M. (2013a): “Dr. Marko Snoj: “Danes stare mame govorijo ful!”. Mladina, Intervju, 1. 3. 2013. Dostopno prek: http://www.mladina.si/120969/dr-marko-snoj-danes-stare-mame-govorijo-ful/ (28. 12. 2014).

Snoj, M. (2012): Podgesla v novem slovarju slovenskega jezika. V: F. Marušič in R. Žaucer (ur.): Škrabčevi dnevi 7 - zbornik prispevkov s simpozija 2011: 96-103. Nova Gorica: Založba Univerze v Novi Gorici.

Snoj, M. (2009): razprava. V: A. Perdih (ur.): Strokovni posvet o novem slovarju slovenskega jezika, 23. in 24. oktober 20o8. Ljubljana: Založba ZRC SAZU, ZRC SAZU.

SSKJ: Slovar slovenskega knjižnega jezika 1970-1991. Prva knjiga A-H (1970) z Uvodom IX-LXII; Druga knjiga I-Na (1975); Tretja knjiga Ne-Pren (1979); Četrta knjiga Preo-Š (1985); Peta knjiga T-Ž (1991) z dodatki AŠ. Ljubljana: SAZU, Inštitut za slovenski jezik, Državna založba slovenije.

Suhadolnik, S. in Klopčič, M. (1970): Slovar slovenskega knjižnega jezika. Glavne značilnosti slovarja. Naši razgledi (6. 3.): 137.

Škofic, J. (2009): Oznake za izgovorjavo v novem slovarju slovenskega jezika. V: A. Perdih (ur): Strokovni posvet o novem slovarju slovenskega jezika, 23. in 24. oktober 20o8: 135-144. Ljubljana: Založba ZRC, ZRC SAZU.

Šorli, M. (2014): Sodobni sporazumevalni slovar slovenskega jezika: izhodišča, viri, izvedba. V: S. Bergoč in I. Grahek (ur.): Novi slovar za 21. stoletje: E-zbornik prispevkov s Posveta o novem slovarju slovenskega jezika na Ministrstvu za kulturo 12. 2. 2014, Ljubljana, april 2014: 14 str. Ljubljana: Ministrstvo za kulturo.

Verdonik, D. in Zwiter Vitez, A. (2011): Slovenski govorni korpus Gos. Ljubljana: Trojina, zavod za uporabno slovensistiko. 
Vidovič Muha, A. (2014): Nastanek Seminarja slovenskega jezika, literature in kulture - čas spremembe jezikoslovnega koncepta. V: H. Tivadar in D. Limon: 5o. Seminar slovenskega jezika literature in kulture: Prihodnost $v$ slovenskem jeziku, literaturi in kulturi: 127-132. Ljubljana: FF: Oddelek za slovenistiko.

Vidovič Muha, A. (2009): razprava. V: Perdih, A. (ur.): Strokovni posvet o novem slovarju slovenskega jezika, 23. in 24. oktober 20o8. Ljubljana: Založba ZRC SAZU, ZRC SAZU.

Vidovič Muha, A. (1992): Normativnost v slovar ujete slovenske besede. Razgledi (10. jan. 1992), 41 (1): 10-11.

Vidovič Muha, A. (1999): Čas in prostor, ujeta v slovenski slovar 20. stoletja: (poudarek na komunikacijskem vidiku Slovarja slovenskega knjižnega jezika). V: E. Kržišnik, M. Lokar (ur.): Zbornik predavanj: 7-26. Ljubljana: Center za slovenščino kot drugi/tuji jezik pri Oddelku za slovanske jezike in književnosti Filozofske fakultete.

Weiss, P. (2009): Skupaj ali narazen v novem slovarju slovenskega jezika. V:

A. Perdih (ur): Strokovni posvet o novem slovarju slovenskega jezika, 23. in 24. oktober 20o8: 145-152. Ljubljana: Založba ZRC, ZRC SAZU.

Žele, A. (2009): razprava. V: Perdih, A. (ur.): Strokovni posvet o novem slovarju slovenskega jezika, 23. in 24. oktober 20o8. Ljubljana: Založba ZRC SAZU, ZRC SAZU.

\section{Korpusi:}

Gigafida. Dostopno prek: http://www.gigafida.net (28. 12. 2014).

Kres. Dostopno prek: http://www.slovenscina.eu/korpusi/kres (28. 12. 2014).

Gos. Dostopno prek: http://www.slovenscina.eu/korpusi/gos (28. 12. 2014).

Nova beseda. Dostopno prek: http://bos.zrc-sazu.si/s_beseda3.html (28. 12. 2014). 


\section{Spletne strani:}

Slogouni priročnik. Dostopno prek: http://www.slovenscina.eu/portali/slogovniprirocnik (28. 12. 2014).

Sloleks. Dostopno prek: http://www.slovenscina.eu/sloleks/opis (28. 12. 2014).

SloWNet. Dostopno prek: http://lojze.lugos.si/darja/research/slownet/ (28. 12. 2014). AWN: Algemeen Nederlands Woordenboek. Dostopno prek: http://www.inl.nl/onderzoek-a-onderwijs/lexicologie-a-lexicografie/algemeen-nederlandswoordenboek in iskalnik: http://anw.inl.nl/show?page=search1 (28. 12. 2014).

Veliki slovar poljskega jezika. Dostopno prek: http://www.wsjp.pl/ (28. 12. 2014).

\section{Spletni vir:}

Noske. Dostopno prek: http://nl.ijs.si/noske/index-en.html (28. 12. 2014). 


\section{A DICTIONARY OF CONTEMPORARY SLOVENE: LEXICOGRAPHIC TRADITION OR/AND INNOVATION}

The Proposal for a Dictionary of Contemporary Slovene, published in May 2013, has stirred many debates in both academic circles and in media. The topic central to all the debates was whether a new dictionary of Slovene should follow the tradition established by the Dictionary of Literary Slovene (published in 1970s), which was based on the structuralist theories of the Prague school, or move away from this tradition. All this lead to differing views on what a dictionary tradition is, and on the role of new lexicographic methods. By analyzing the concepts of the Dictionary of Literary Slovene and the Dictionary of New Slovene Lexis (published in 2012), as well as making an overview of scientific articles dealing with the topic of a concept for a new dictionary of Slovene, this paper attempts to establish which elements of lexicographic theory can be viewed as traditional and which represent innovation in Slovene lexicography. Simultaneously, a concept for a new dictionary is considered from three perspectives: the user, the medium, and the use of language technologies, which would facilitate language description and meet the needs of language community. As the author argues, a new dictionary of Slovene will do well to carefully consider the status of literary language in contemporary Slovene, be corpus-driven and user-oriented (rather than academic), incorporate various lexicographic findings, e.g. use different approaches to defining (depending on their efficiency at different word classes or categories of words), be digital-born, i.e. devised with an online medium in mind, offer updates on a regular basis, and utilize various language technologies, such as automatic example extraction, in its design to facilitate dictionary compilation. Only thus will the new dictionary become a state-of-the-art lexicographic product and a worthy successor to the Dictionary of Literary Slovene.

Keywords: dictionary of contemporary Slovene, lexicographic tradition, stateof-the-art lexicography, dictionary concept 
To delo je ponujeno pod licenco Creative Commons: Priznanje avtorstvaDeljenje pod enakimi pogoji 2.5 Slovenija.

This work is licensed under the Creative Commons Attribution ShareAlike 2.5

License Slovenia.

http://creativecommons.org/licenses/by-sa/2.5/si/

(c) $(1)(0)$ 